DE DE GRUYTER

OPEN

DOI 10.1515/pesd-2017-0001

PESD, VOL. 11, no. 1, 2017

\title{
DRY PERIODS IMPACT ON THE SURFACE WATER QUALITY
}

\author{
Gheorghe Duca ${ }^{1}$, Hong Xiao ${ }^{2}$, Maria Nedealcov ${ }^{3}$, Violeta Ivanov ${ }^{4}$, \\ Anatol Tarita ${ }^{3}$
}

Key words: dry periods, water quality

\begin{abstract}
Current changes of the environment represent the major threats to the sustainable development and are one of the biggest problems, with negative consequences on the national economy. The accelerated pace of these changes is shareholder and by the manifestation of extreme events, which in recent years become more intense and frequent. The drought events frequent manifestation over the Republic of Moldova territory, in the context of climate change, requires a scientific monitoring adjusted.

The dry period's manifestation is greatly conditioned by increasing daytime temperatures (above $25^{\circ} \mathrm{C}$ ) and the lower relative humidity (below 30\%). At present, on the background of climate change, there is an increase of dry days. Over the Republic of Moldova territory, their occurrence during growth and development of crops particularly damaging role in obtaining low yields. Meanwhile, prolonged dry periods, may possibly cause fires, at the same time can determine lands' irrigation and surface water quality.

In this context, there is a need to estimate the evaporation's spatial and temporal variability, the number of dry days and their correlation to Dry Periods Index (Izu), the index developed at regional level.
\end{abstract}

\section{Introduction}

Climatic changes' accelerated rate on Republic of Moldova's territory in the last decades brings drought periods' installation that contributes to climatic water deficits. In country's conditions and unstable humidification regime they influence the quality of surface waters for certain years. Thus, along with pollution provoked

\footnotetext{
${ }^{1}$ Moldova's Academy of Sciences, Republic of Moldova

${ }^{2}$ Associate Professor, Sichuan University, China

${ }^{3}$ Institute of Ecology and Geography, ASM, Republic of Moldova

${ }^{4}$ Parliamentary Committee for public administration, regional development, environment and

climatic changes, Republic of Moldova
} 
by anthropic activity, dry periods' influence of surface waters may be substantial, from decrease in annual water's debit in rivers till substantial reduction of lakes' area. Taking into account that drinking water resources are limited on the regional level, we consider that the knowledge of spatio-temporal variability of climatic indexes characterizing dry periods and climatic water deficit, aiming to determine their possible impact on surface waters' quality is of extreme importance.

\section{Initial materials and investigation methods}

Thermic extremes' variability estimation if the given work is based on plots which on the present stage facilitate considerably to domain of climatic variabilities' calculation within the limits of the three sigmas. Using the corresponding procedures in Statgraphics Centurion XVI software, the estimations can be executed in many stages.

During the first stage or initial research we determine the so-called "control limits" that are assumed from time series data. The "central line" is the multiyear average and usually is situated in the middle of data that represent observations' mean value according to this expression:

$$
\bar{x}=\frac{\sum_{i=1}^{n} x_{i}}{n}
$$

"Control limits" are placed over and under the central line at:

$$
\bar{x} \pm k \hat{\sigma}
$$

- where $\mathrm{k}$, is muliple sigma specified control plot's file.

This procedure allows the user to determine thermic regime's variability within the limits of the three sigmas by „limiting the zone” of multiyear data. Such procedure substantially simplifies statistical calculations and also allow concomitant estimations of different levels of variability on the time scale (fig.1).

The initial materials for investigations are multiyear data on atmospheric precipitations' regime, mean monthly temperature and mean monthly air's relative humidity for 1961-2015, collected from meteorological stations of State Hydrometeorological Service. 


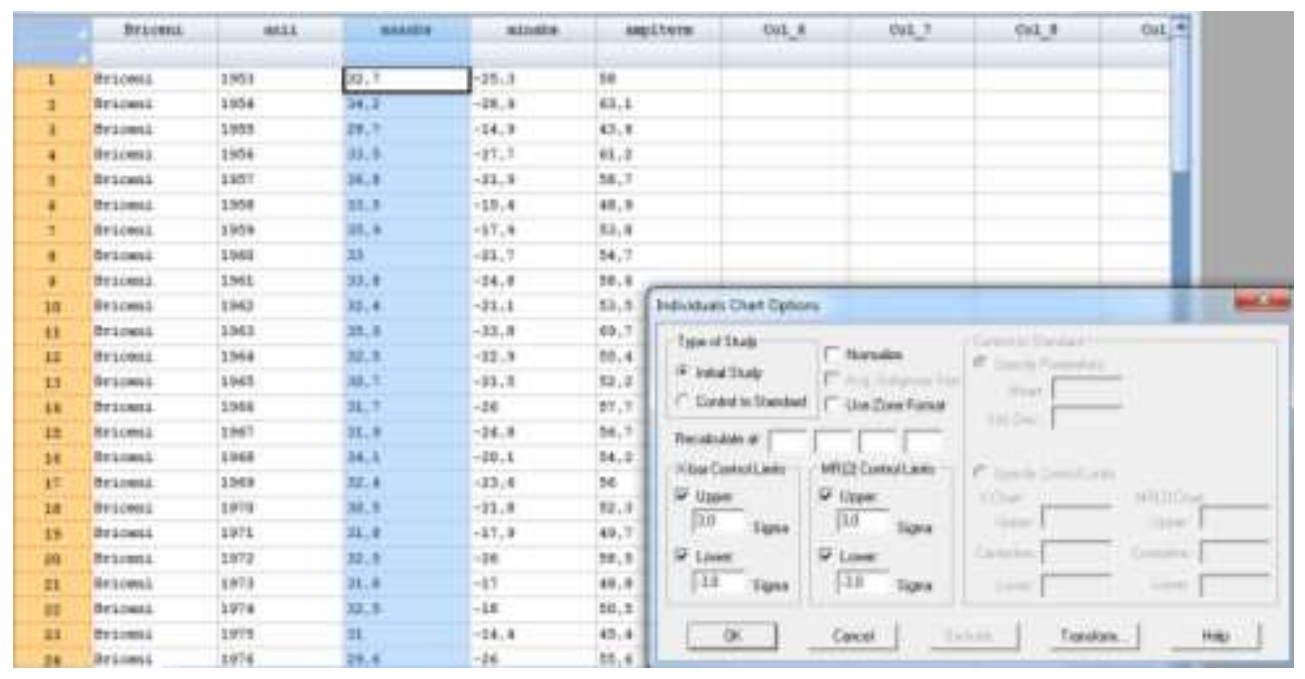

Fig.1. Estimations of control limits of thermic regime's variability

The limited presence in space of evaporability conditioned the necessity of its calculation based on the known indexes.

According to the previously obtained results [2], the nearest to the factological data are timeseries calculated by N.Ivanov's evaporability formula, where it is obtained by relation:

$$
\mathrm{E}_{0}=0,0018(25 \pm \mathrm{t})^{2}(100-\mathrm{a}),
$$

$\mathrm{t}$ - mean monthly air temperature;

a - mean monthly air's relative humidity.

The difference between annual (or monthly) values of precipitations and evaporability $\left(\mathrm{E}_{0}\right)$ represent annual or monthly climatic water deficit $(D E F)$, with the negative sign [1]. It has the following expression:

$$
D E F=\mathrm{P}-\mathrm{E}_{0}
$$

By contribution of E0 instead of temperature (if compared this formula to another complex indexes), and also by that of atmospherical precipitations that have the same measure unit as E0 ( $\mathrm{mm})$, this index is especially useful when estimating the adequacy of humidification regime. 
We should mention, that a special attention is paid for the following months of the vegetation period: may, june and july, so it would also be a good idea to calculate DEF index for these separate months.

As the duration of dry days in may-august directly influences the main ontological phases of agricultural species' development, we also propose to take into consideration the Dry Days Index $(I z u)$, elaborated on the regional level. It represents a relation between the sum of dry days registered in certain years and their multiyear average for the above mentioned period [3]:

$$
I z u=\frac{\sum z u_{(V-V I I I)}}{\bar{X} z u_{(V-V I I I)}},
$$

where $\Sigma z u_{(V-V I I I)}-$ dry days sum registered during a period (may-august), when agricultural species are growing and intensively, $\bar{X} z u_{(V-V I I I)}-$ multiyear average of dry days (may-august)

Table 1. Assessment system of Nedealcov Index of Dry Days Periods te $(I z u)$

\begin{tabular}{cl}
\hline Izu Values & Izu Assessment system \\
\hline $\mathbf{0 , 1 - 1 , 0}$ & normal period \\
$\mathbf{1 , 1 - 2 , 0}$ & Moderately dry period \\
$\mathbf{2 , 1 - 3 , 0}$ & Significantly dry period \\
$\mathbf{3 , 1 - 4 , 0}$ & Dangerously dry period \\
$\mathbf{> 4 , 1}$ & Exceptionally dry period \\
\hline
\end{tabular}

Izu Assessment system allows determining of aridity degree by determining of dry days periods. In the case then $I z u$ values are equal to 2.1, dry days sum exceeds twice their multiyear average, and the period of significantly dry weather is installed. (tab.1).

By its physical essence this index is complex thereas dry days are considered such when duirnal temperatures constitute $25^{\circ} \mathrm{C}$ or more, iar and air's relative humidity is less than $30 \%$. We should also mention, that the above presented indexes was also applied on the territories neighbouring with Republic of Moldova $[3,4,5]$.

The country's natural conditions' specifics determines the necessity of spatial estimations conditioned by zonal and azonal physical-geographical factors (geographic latitude and longitude, absolute and relative altitude, slopes' orientation and inclination), that contribute to climatic data redistribution for the areas lacking sistemic observations. Thus, regression equations calculation (as dependent variable we used time series for DEF calculated for meteorological 
stations, and as independent variables we used data that characterizes physicalgeographical factors of stations' placement) helped usto elaborate cartographical models, which allowed to elaborate for the first time digital maps on spatial distribution of DEF on the level of the country and hydrographic basin (Prut River).

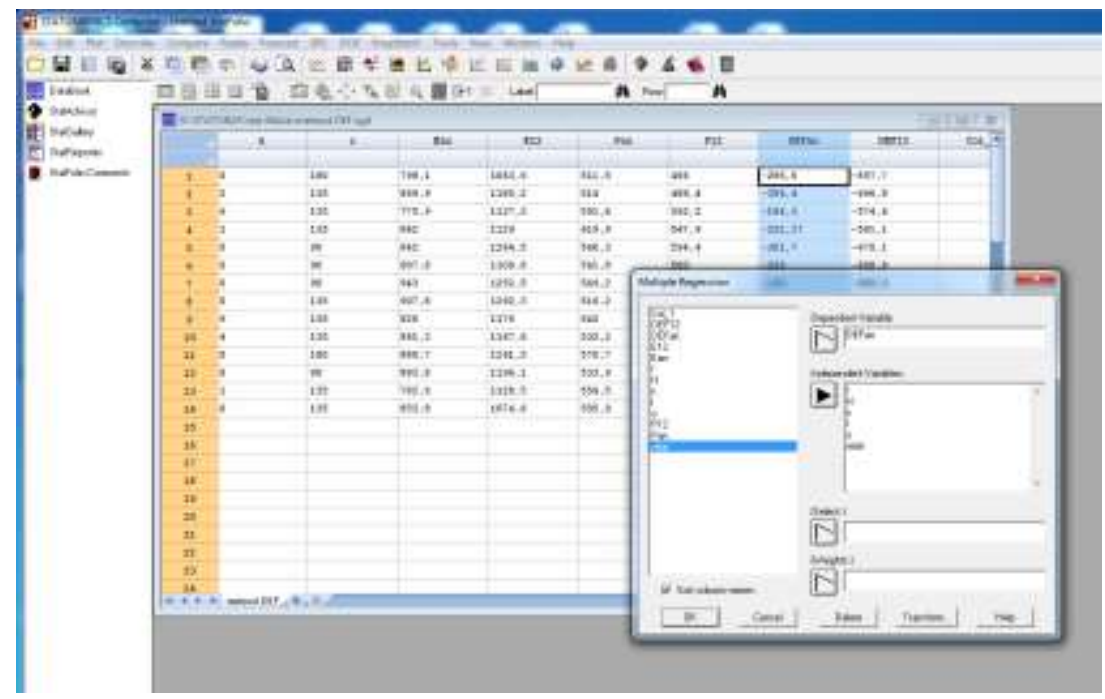

Fig.2 Determining the influence of physical-geographical factors in DEF annual's spatial redistribution

The data that estimates surface waters' quality was collected for the Guide of surface waters quality, elaborated by State Hydrometeorological Service [6], according to the Water Pollution Index (IPA). We should mention that IPA is estimated by 7 classes and is calculated by a fixed number of parameters (6): ammonium nitrate, nitrite nitrogen, petrolium products, phenols, dissolved oxygene and biochemical consuming of oxygene during 5 days. The formula is as follows:

$$
\frac{C i}{C M A-2 i \sigma}
$$

where:

$C i$ - parameters' average concentration;

$C M A i$ - parameters' maximum allowable concentration;

6 - number of the parameters used in calculation. 


\section{Obtained results' analysis}

Maximum temperatures' regime in republic's Northern part, especially during the last years (2000-2015) under the central line (that is their climatic norm) was
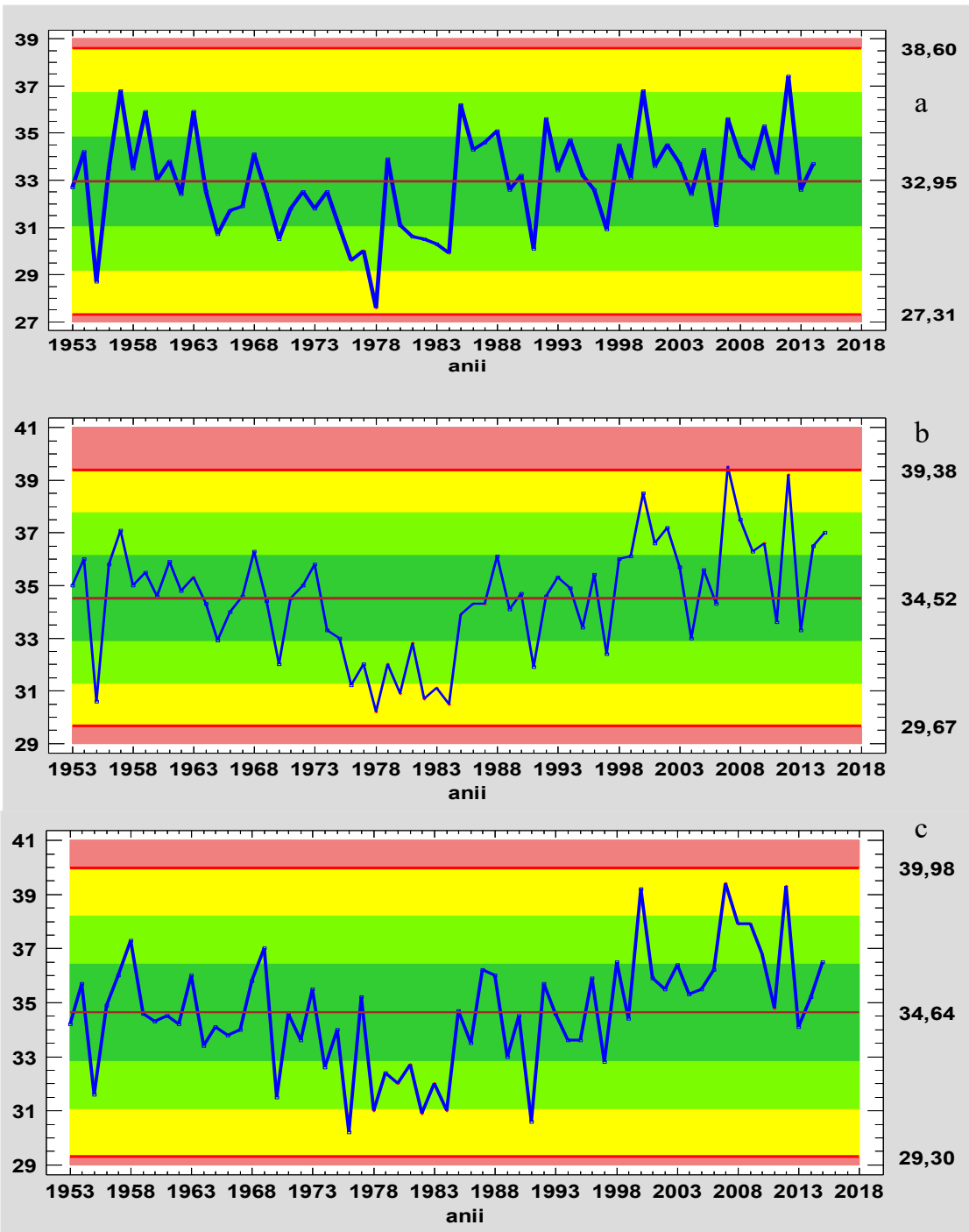

Fig. 3. Absolute maximum's variability within the limits of the three sigmas (a-Briceni, b-Chișinău, c-Cahul)

registered only once, the rest of the years had values that greatly exceed the level of the central line. In the certain past years $(2000,2007,2009,2012)$, thermic 
values were more than $35^{\circ} \mathrm{C}$. We should mention that central line in republic's Northen part that coincides with multiyear average is equal to $32,95^{\circ} \mathrm{C}$ (fig. $3 \mathrm{a}$ ).

Central line corresponds to the value of $34,52^{\circ} \mathrm{C}$ in republic's central parts. Thus, in three cases one can observe the values below the climatic norm, though it is also significant $\left(35,0^{\circ} \mathrm{C}\right) .11$ years are above the central line with the values of $36,0^{\circ} \mathrm{C}$ and more (fig. $3 b$ ).

The central line in republic's southern parts is approximately the same as the values that characterize absolute maximum values regime in republic's central parts $\left(34,64^{\circ} \mathrm{C}\right)$. Below the central line, i.e. below multiyear average we can observe just a single case, but with essential values $\left(35,0^{\circ} \mathrm{C}\right)$. Above the value of $36,0^{\circ} \mathrm{C}$ we have 14 cases (fig. $3 \mathrm{c}$ ).

All above-mentioned indicates that absolute maximum temperatures values' intensity and frequency is increasing during past two decades, which shows that dry days period continues to be and that probably this tendency would still be present in the nearest future as well.

Dinamics' analysis of Dry periods index (Izu) and especially its values above the limit of significantly dry periods indicate that this limit was exceeded 4 times on the timescale (fig.4a), and in southern parts of republic within the same reference period (1960-2015), we have registered 7 cases (fig.4b).

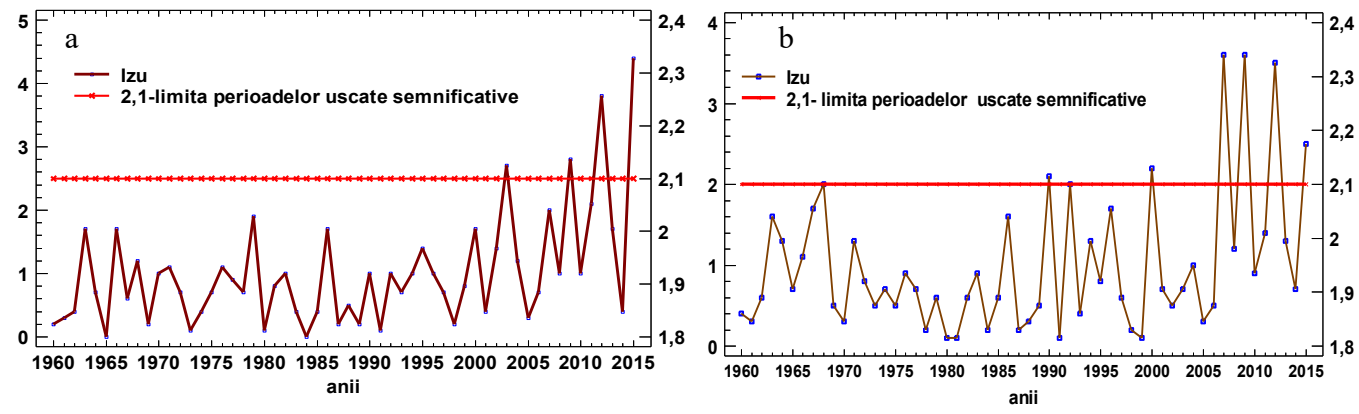

Fig. 4. The evolution of Dry Periods Index, Izu (1960-2015) (a- Briceni; right-Cahul)on Republic of Moldova's territory

We should also mention, that the most significant values of $I z u$, in both Northern and Southern parts were registered in 2007, 2009, 2012, 2015. But, as they are dependent of physical-geographical position (North-South), these extreme values have varied from year to year.

Thus the quantile plot (fig.5) of Dry periods Index (Izu) indicates that extremely dry years ( 4 to count) are identified in northern parts of the republic (fig.5a) and are in descending chronological order $-2015,2012,2009,2007$. In South of republic we identify the inverted chronology (fig.5b): 2007, 2009, 2012, 2015. 

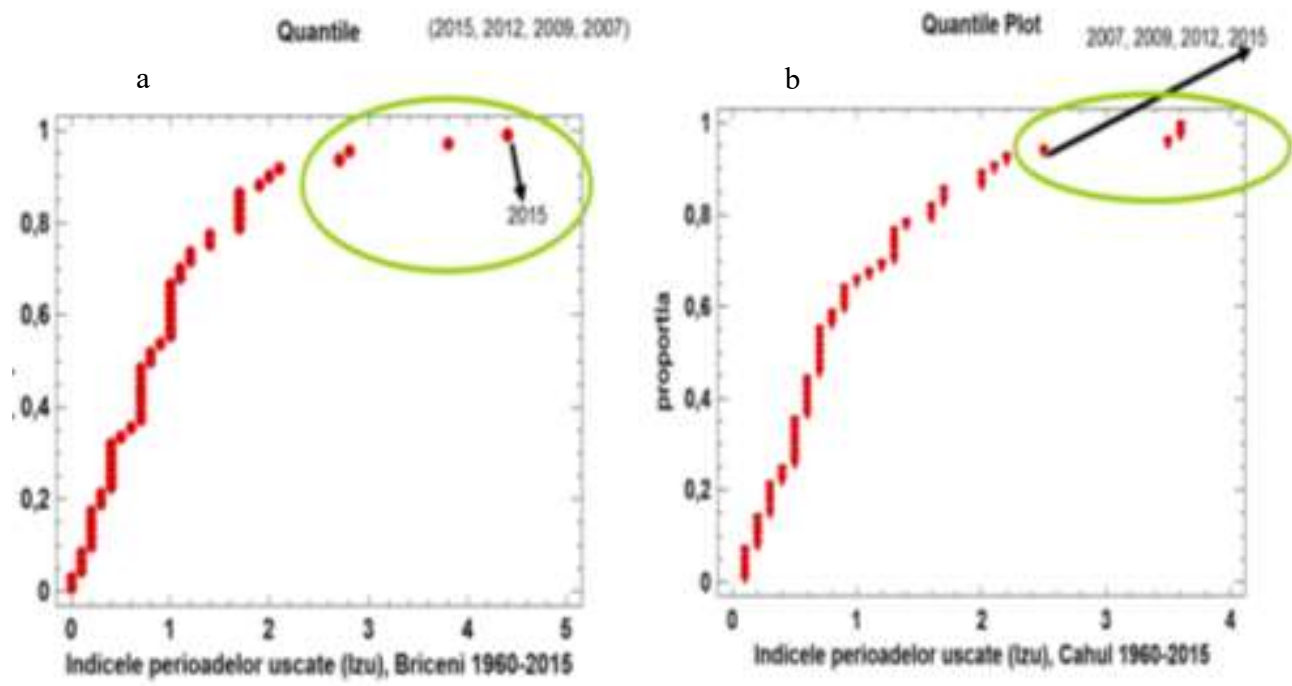

Fig. 5. Dry periods Index's quantile plot (Izu) with extreme years identified in Northern (a) and Southern (b) parts of Republic of Moldova

Likewise speaking about the northern parts of the country one should mentionthat year 2015 has registered, among the four significantly dry years, the values that characterize the may-august period as dangerously dry period, whereas the year 2007 in republic's South was especially dangerously dry for the same months.

Thus according to the extreme values theory one should observe that the return period for extremely dangerous periods in may-august can be relatively short and can be within the same decade, fact which allows concluding that we're on a verge of substantial climatic changes.

Tab nr. 1. Statistical indexes that characterize annual evaporability values (mm) in 19612015 period

\begin{tabular}{cccc}
\hline Statistical indexes & Briceni & Chisinau & Comrat \\
\hline $\mathrm{X}$ & 704,1 & 942,9 & 907,8 \\
$\mathrm{CV}$ & $16,7 \%$ & $14,2 \%$ & $15,1 \%$ \\
Minimum & 454,5 & 658,5 & 644,4 \\
Maximum & 1080,4 & 1343,0 & 1292,3 \\
\hline
\end{tabular}

Significantly dry periods condition climatic water deficit which in its turn being sensible to the registered evaporability values. 
That is why a database of annual evaporability values for republic's territory has been calculated and elaborated, which states that the highest values in multiyear aspect are registered in republic's central (Chișinău... 942,9 mm) and southern parts(Comrat... 907,8 mm). Maximum values vary within the limits of $1292-1343 \mathrm{~mm}$.

At the same time we should mention that the once per ten years dry years can have $\mathrm{E}_{0}$ of nearly $1106.3-1132.2 \mathrm{~mm}$ in republic's central and southern parts, which should be taken into account when determining climatic water deficit and irrigation norms (tab.2).

Tab. nr. 2. Evaporability with various probability degree (\%) on Republic of Moldova's territory

\begin{tabular}{cccc}
\hline Probability & Briceni & Chisinau & Comrat \\
\hline $1,0 \%$ & 454,5 & 658,5 & 644,4 \\
$5,0 \%$ & 541,5 & 743,8 & 705,1 \\
$10,0 \%$ & 569,5 & 805,2 & 768,7 \\
$25,0 \%$ & 624,1 & 843,5 & 818,2 \\
$50,0 \%$ & 701,8 & 943,0 & 875,1 \\
$75,0 \%$ & 769,0 & 1008,0 & 968,9 \\
$90,0 \%$ & 847,5 & 1132,2 & 1106,3 \\
$95,0 \%$ & 951,7 & 1252,5 & 1189,3 \\
$99,0 \%$ & 1080,4 & 1343,0 & 1292,3 \\
\hline
\end{tabular}

Evaporability's intensity and frequency estimation in republic's North (tab.3) in the annual aspect demonstrates that in the rarest cases (44 out of 55 years), evaporability varies within the limits of $550-820 \mathrm{~mm}$.

Table nr. 3. Evaporability's intensity and frequency of manifestation in republic's North (Briceni st.), Republic of Moldova

\begin{tabular}{cccc}
\hline Class & Lower Limit & Upper Limit & Frequency \\
\hline 1 & 420,0 & 464,4 & 1 \\
2 & 464,4 & 508,8 & 0 \\
3 & 508,8 & 553,3 & 2 \\
4 & 553,3 & 597,7 & 5 \\
5 & 597,7 & 642,2 & 11 \\
6 & 642,2 & 686,6 & 7 \\
7 & 686,6 & 731,1 & 12 \\
8 & 731,1 & 775,5 & 4 \\
9 & 775,5 & 820,0 & 5 \\
10 & 820,0 & 864,4 & 3 \\
\hline
\end{tabular}




\begin{tabular}{cccc}
\hline Class & Lower Limit & Upper Limit & Frequency \\
\hline 11 & 864,4 & 908,8 & 2 \\
12 & 908,8 & 953,3 & 1 \\
13 & 953,3 & 997,7 & 1 \\
14 & 997,7 & 1042,2 & 0 \\
15 & 1042,2 & 1086,6 & 1 \\
16 & 1086,6 & 1131,1 & 0 \\
17 & 1131,1 & 1175,5 & 0 \\
18 & 1175,5 & 1220,0 & 0 \\
\hline
\end{tabular}

The country's central part (tab.4), in 47 per 55 years, has annual evaporability that varies within the limits of $797,8-1153,3 \mathrm{~mm}$.

Tab. nr.4. Evaporability's intensity and frequency of manifestation in republic's Center (Chişinău st.), Republic of Moldova

\begin{tabular}{cccc}
\hline Class & Lower Limit & Upper Limit & Frequency \\
\hline 1 & 620,0 & 664,4 & 1 \\
2 & 664,4 & 708,8 & 0 \\
3 & 708,8 & 753,3 & 2 \\
4 & 753,3 & 797,7 & 1 \\
5 & 797,7 & 842,2 & 9 \\
6 & 842,2 & 886,6 & 6 \\
7 & 886,6 & 931,1 & 8 \\
8 & 931,1 & 975,5 & 9 \\
9 & 975,5 & 1020,0 & 8 \\
10 & 1020,0 & 1064,4 & 4 \\
11 & 1064,4 & 1108,8 & 1 \\
12 & 1108,8 & 1153,3 & 2 \\
13 & 1153,3 & 1197,7 & 1 \\
14 & 1197,7 & 1242,2 & 0 \\
15 & 1242,2 & 1286,6 & 1 \\
16 & 1286,6 & 1331,1 & 1 \\
17 & 1331,1 & 1375,5 & 1 \\
18 & 1375,5 & 1420,0 & 0 \\
\hline
\end{tabular}

Although it would seem that these values are highest in the spatial aspect, republic's southern parts register a more increased frequency of annual evaporability, which constitutes $743,3-1143,3 \mathrm{~mm}$ in 49 cases out of 55 years. 
Tab. nr.5. Evaporability's intensity and frequency of manifestation in republic's South (Comrat st.), Republic of Moldova

\begin{tabular}{cccc}
\hline Class & Lower Limit & Upper Limit & Frequency \\
\hline 1 & 610,0 & 654,4 & 1 \\
2 & 654,4 & 698,8 & 1 \\
3 & 698,8 & 743,3 & 1 \\
4 & 743,3 & 787,7 & 8 \\
5 & 787,7 & 832,2 & 7 \\
6 & 832,2 & 876,6 & 10 \\
7 & 876,6 & 921,1 & 4 \\
8 & 921,1 & 965,5 & 9 \\
9 & 965,5 & 1010,0 & 3 \\
10 & 1010,0 & 1054,4 & 2 \\
11 & 1054,4 & 1098,8 & 3 \\
12 & 1098,8 & 1143,3 & 3 \\
13 & 1143,3 & 1187,7 & 0 \\
14 & 1187,7 & 1232,2 & 1 \\
15 & 1232,2 & 1276,6 & 1 \\
16 & 1276,6 & 1321,1 & 1 \\
\hline
\end{tabular}

Rate estimation of multiyear evaporability $\left(\mathrm{E}_{0}\right)$, annual atmospheric precipitations $(\mathrm{P})$ and climatic water deficit (DEF), reveals the fact that the most unessential values of annual cliamtic water deficit are registered in republic's North (fig.6a). In the same area the highest values were registered in 2015, when climatic water deficit's value $(D E F)$ was equal to $-701,1 \mathrm{~mm}$, which is $-84,2 \mathrm{~mm}$ less than multiyear average registered during 1961-2015 period.

In republic's central parts, concomitant evolution of evaporability, annual atmospheric precipitations and climatic water deficit indicates that annual cliamtic water deficit's values increase essentially (fig.6b), and constitute values under -600 $\mathrm{mm}$ in the past few decades, while multiyear average is $-393,7 \mathrm{~mm}$, and deficit's maximum is equal to $-913 \mathrm{~mm}$, registered in 2015 . 

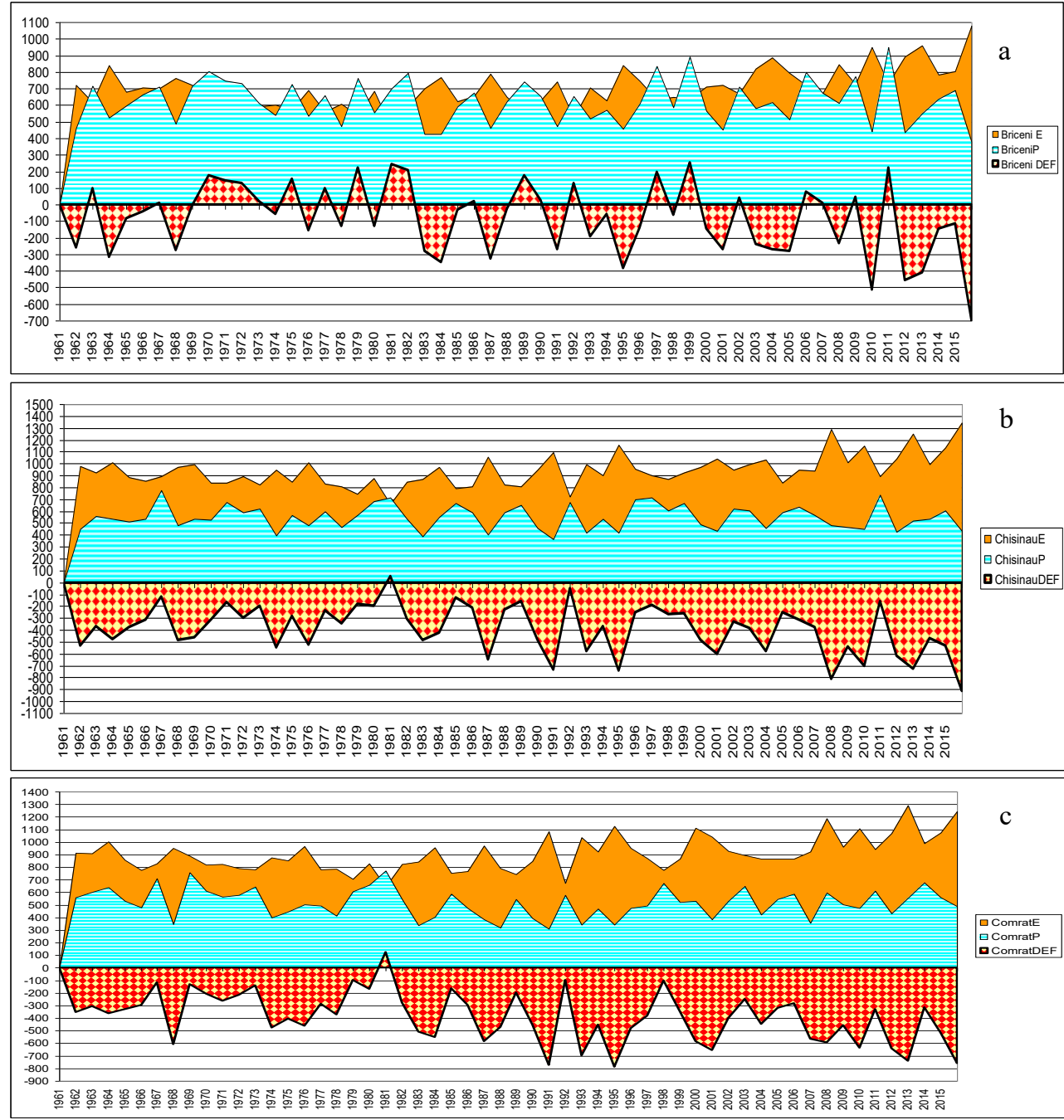

Fig. 6. Concomitant evolution of evaporability $\left(\mathrm{E}_{0}\right)$, annual atmospheric precipitations $(\mathrm{P})$ and climatic water deficit (DEF) (a- Briceni; b-Chisinău; c-Comrat)

In republic's South, the temporal analysis of evaporability, annual atmospheric precipitations and climatic water deficit reveals the fact that $D E F$ index in the majority of cases (fig.6c) ranges within that limits of $-600 \ldots-700 \mathrm{~mm}$, while multiyear average is equal to $-391,5 \mathrm{~mm}$. As it was in previous case, the most significant values are registered in 2015 (-913 mm). 
Annual $D E F$ essential values during past years were registered in 2010, 2012, 2013 on the whole Republic of Moldova's territory, which once more is confirmed on monthly temporal scale, with a scope of irrigation norms regulations. Thus the knowledge of climatic water deficit manifestation's intensity and frequency would contribute to setting the irrigation-specific standards and consequently would also contribute to correct usage of potable water resources.

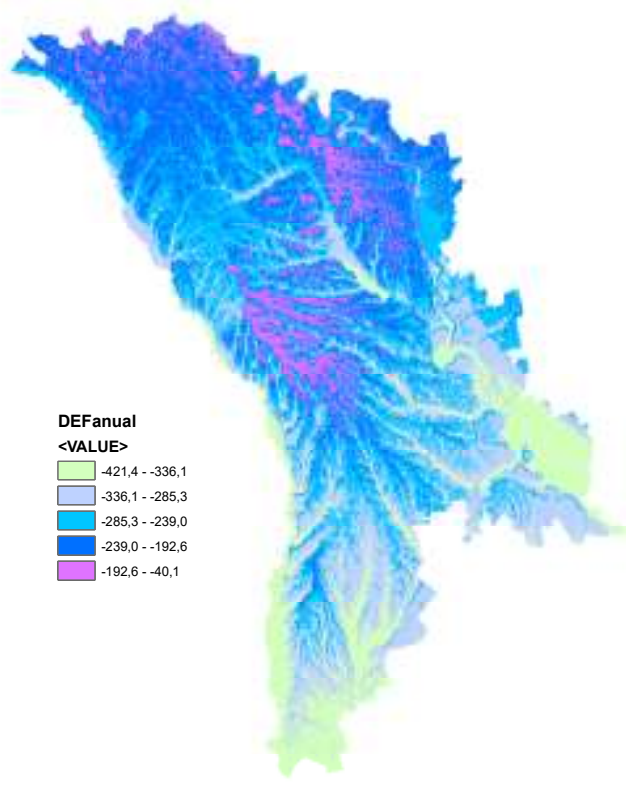

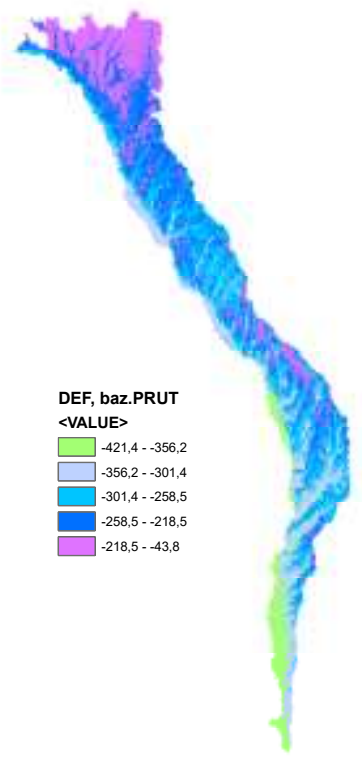

Fig.7. Climatic water deficit's spatial distribution in regional aspect Republic of Moldova) and a river's basin (b- Prut River)

Selecting the areas with the most essential values of climatic water deficit would allow setting irrigation demand-specific standards. Thus we had elaborated the mapof spatial distribution of $D E F$ index for all republic's territory in river basins' aspect (fig.7a, 7b), which would allow to select the areas with irrigation water natural necessities.

Taking into account local geographical conditions' particularities within republics boundaries and also the necessity of improvements in population's provision with drinking water, we had elaborated cartographical models of climatic water deficit on the level of administrative regions. (fig.8)

The digital maps elaborated on the basis of two administrative regions (Briceni Region situated in republic's North and Cahul Region, in republic's 
South) demonstrate that $D E F$ index increases from North-Western parts (where this index is within $-192,0 \ldots-136,8 \mathrm{~mm}$ ) till South-Eastern ones (its values being within $-298,5 \ldots-254,7 \mathrm{~mm}$ ) within Briceni Region's boundaries, thus the spatial varibility constitutes $-161,7 \mathrm{~mm}$, a value indicating the necessity of differntiated irrigation in the given territory (fig.8a).

a

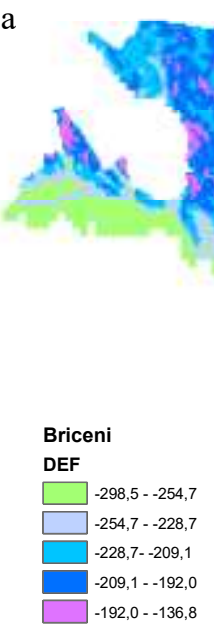

$\mathrm{b}$

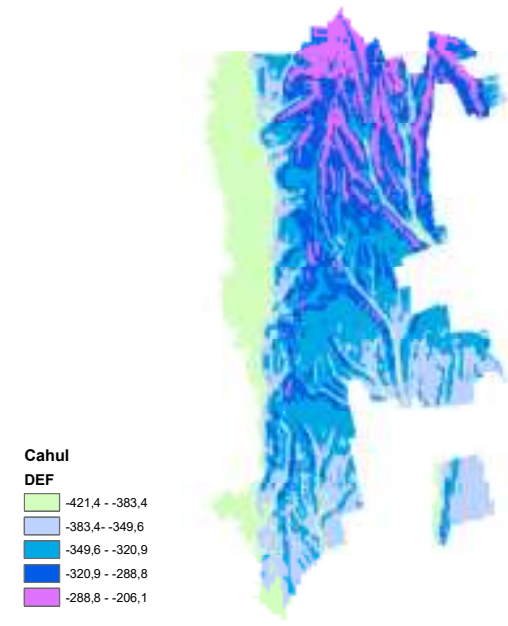

Fig.8. Climatic water deficit's spatial distribution on the level of administrative regions ( $\mathrm{a}$ - Briceni Region, $\mathrm{b}$ - Cahul Region)

We should also mention that CahulRegion situated in Southern parts of the country has more essential spatial varibility, which constitutes $-215,3 \mathrm{~mm}$. $D E F$ Index's values differ numerically from the values that are characteristic for Briceni Region. The Prut River's valley has values of $-421,4 \mathrm{~mm} . . .-383,4 \mathrm{~mm}$, and in Chul Region's Northern parts on the altitudes one can observe climatic water deficit equal to $-288,8 \ldots-206,1 \mathrm{~mm}$. Undoubtedly, that the knowldge of numericl values for climatic water deficiton the local level would greatly improve drinking water resources' management.

Climatic water deficit's spatial distribution reveals that the country's South and South-East sums the most essential values. 


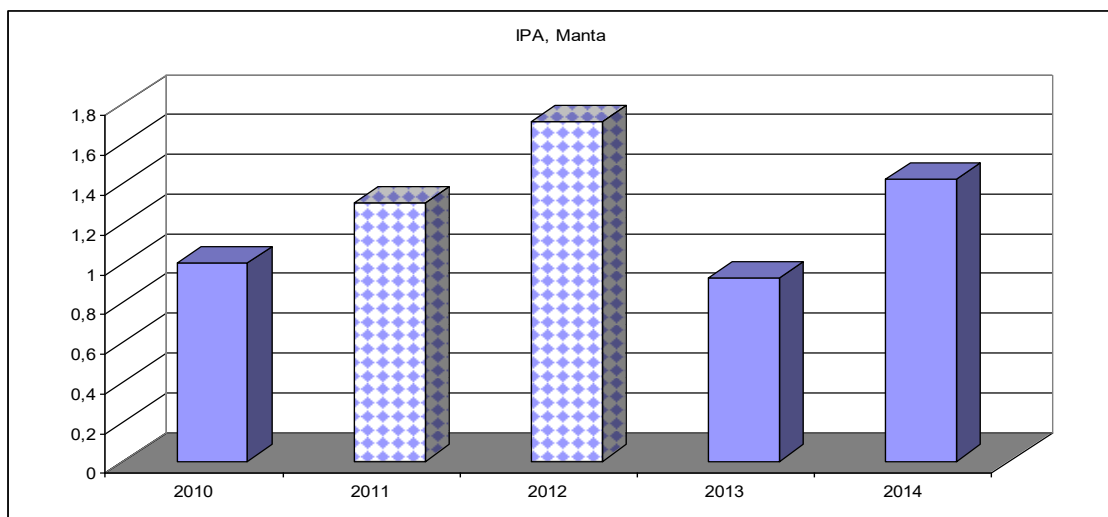

Fig.9. Lake Manta's water quality according to WPI (IPA) during 2010-2014

Thus we are able to state that if we consider the Prut River's inferior parts during the past few years, then the significant evaporability and substantial annual climatic water deficit provoked majorly by dangerously dry periods installed in may-august not only have contributed to river's water debit decrease, but also led to water surface shrinkage in Lakes Manta and Beleu, worsening rapidly their waters' quality (fig.9, fig. 10).

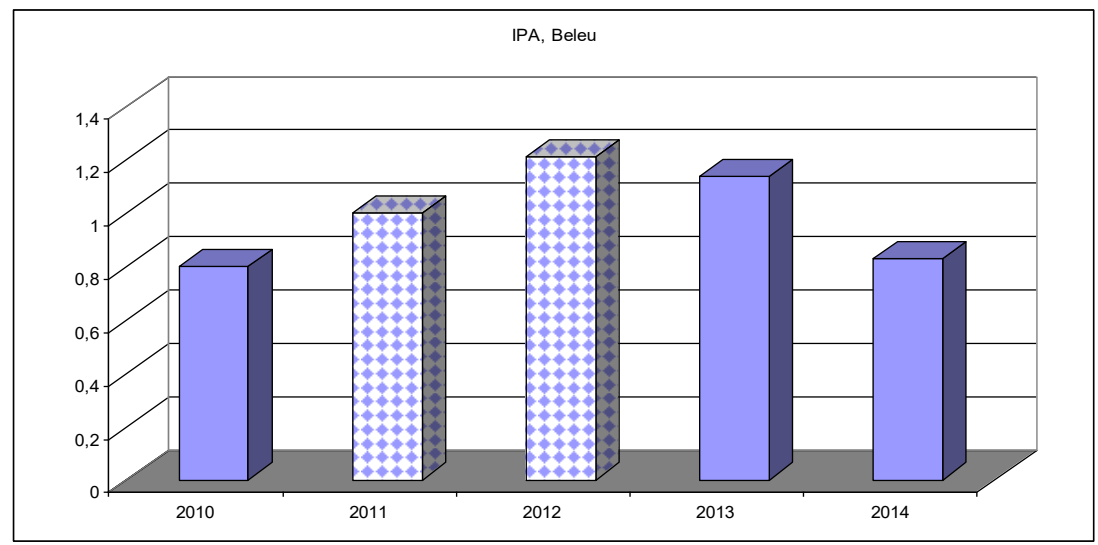

Fig.10. Lake Beleu water quality according to WPI (IPA) during 2010-2014

Thus according to Water Pollution Index (WPI) data [6], when we consider Lake Manta in 2011 and 2012, we are able to state that during this period the most essential values of the above-mentioned index determined by the lowest climatic water deficit's values $(-685,2$ and $-670,1 \mathrm{~mm}$ correspondingly, while $-301,7 \mathrm{~mm}$ is the multiyear average, and $D E F$ absolute value is twice as big as regional climatic 
norm) are qualifying this lake's water quality from II quality class (clean) to III quality class (moderately polluted) (fig.9).

The similar situation can be observed when we consider water quality in Lake Beleu. The high degree of evaporability $(1264,5$, while 842 is multiyear average value) registered in 2012 , for example, led to water quality decrease from II quality class (clean) to III one (moderately polluted) (fig.10).

In conclusion we are able to state that revealed regularities of spatio-temporal distributions of Dry Periods Indexes (Izu), of climatic water deficit $(D E F)$ and identified areas vulnerable to hidrologic necessary would allow to apply differenced time- and space-specific irrigation standards, thus assuring the effective usage of limited drinking water resources in various practical activities, including the agricultural one.

\section{References}

1. Albu Anca-Nicoleta Relaţia Climă-Vegetaţie în Dobrogea de Sud // rezumatul tezei de doctorat, Editura Universităţii din Bucureşti, Iaşi, Bucureşti, 2009, 48 p.

2. NEDEALCOV M., et all. Various Calculation Indexes For Evaporability For Republic Of Moldova's Territory: 2010- 038 Conference on Water Observation and information system for decision support, Ohrid, Republic of Macedonia www.balwois.com/2010.

3. NEDEALCOV, M., CASTRAVEȚ T., ADAMENKO T. The agro-climatic zoning within Dniester River Bazin using GIS technologies. Lucrările Simpozionului Sisteme Informaţionale Geografice Ediţia XXII-a. 2015, Chişinău, Republica Moldova. p. 1722. ISBN 978-9975-97744-9-4.

4. STANA O., et all. Climatic Changes impact on water-table levels in $W$ Romania. Proceeding of the $13^{\text {th }}$ International Conference of Enviromental Science and Technology. Athens, Greece, 5-7 September 2013.

5. RARES HALBAC-COTOARA-ZAMFIR A view on land degradation and desertification issues. Zbornik Radova. Symposium "Actual Tasks on Agricultural Engineering", Opatija, Croatia, 2014.

6. Anuar. Starea calității apelor de suprafață conform indicilor hidrochimici pe teritoriul Republicii Moldova, Serrviciul Hidrometeorologic de Stat. Chișinău, 2015, 157 p. 